\title{
THE PRINCIPLE'S RULE OF NO PAR VALUE SHARES OF TRADING IN STOCK
}

\author{
Nur Sayidah and Ida Keriahenta Silalahi \\ Law Faculty and Economic Faculty of Dr. Soetomo Surabaya University \\ E-mail: nsayidah@yahoo.co.id
}

\begin{abstract}
Regulation of no par value shares in Indonesia is necessary because the stock market can not apply article 31 paragraph (2) of the Company Law number 40, 2007 because there is no further adjustment. This condition are known with the legal vacuum. The purpose of this article is to find the model of no par value shares regulation in Indonesia Capital Market. Further regulation of no par value shares is needed to fulfill this legal vacuum. Research method in this artikel is using normative approach. The results show that regulation of no par value share must fulfill four principles. There are (a) the principle of workable (b) the principle of global nature (compatible for domestic exchange rules and the world exchange rules), (c) the principle of legal certainty in justice (d) the principle of legal protection.
\end{abstract}

Key words: capital market, legal certainty, no par value shares.

\begin{abstract}
Abstrak
Pengaturan saham tanpa nilai nominal sangat diperlukan karena pasar modal tidak bisa menerapkan Pasal 31 ayat (2) UUPT 2007 karena belum ada pengaturan lebih lanjut. Konsep saham tanpa nilai nominal belum ada di UUPM sehingga menyebabkan adanya kekosongan hukum (leemten in het recht). Tujuan artikel ini adalah untuk menemukan model pengaturan saham tanpa nilai nominal di pasar modal Indonesia. Perlu pengaturan lebih lanjut tentang saham tanpa nilai nominal untuk mengisi kekurangan tersebut. Metode penelitian dalam artikel ini menggunakan pendekatan normatif. Hasilnya menunjukkan bahwa model pengaturan saham tanpa nilai nominal harus memenuhi empat prinsip. Keempat prinsip tersebut adalah (a) prinsip dapat diterapkan (workable) oleh pelaku pasar modal (b) prinsip bersifat global (compatible for domestic exchange rules and the world exchange rules) (c) prinsip memberi kepastian hukum yang memenuhi rasa keadilan (legal certainty in justice); (d) prinsip mampu memberikan perlindungan hukum (law protection) kepada pelaku pasar modal termasuk stakeholder dari pelaku pasar modal.
\end{abstract}

Kata kunci: pasar modal, kepastian hukum, saham tanpa nilai.

\section{Introduction}

The basic issuance of no par value shares is to anticipate the needs of issuers who will restructure the company's capital and restructuring the business world. This restructuration is done when the market value of the company's stock had fallen to below nominal value. By setting the issuance of no par value shares allows the deposit of shares is determined by market value.

The rule of no par value shares indicated in Article 31 paragraph (2) of Act 40 of the Company (referred as the Company Law). The gene- ral provisions of the Company Law in 2007 stated that the entire capital of the Company consists of shares. Implied stock are a shares with a nominal value which is affirmed in Article 49 paragraph 2 . The company which is already listed on the stock exchange have the opportunity to issue the no par value shares. This opportunity until now could not be used because there is no further regulation. The concept of no par value shares have not been attached in the Capital Markets Act so that no legal problems in its application. This juridical problems caused a legal vacuum that needs to be filled with an 
arrangement. There are several legal principles that must be met in an arrangement. This article discusses the principles in the regulation of no par value shares in trading in Indonesia.

\section{Issues}

The problems which discussed in this research article is about The Principle's Rule of No Par Value Shares of Trading In Stock in Indonesia.

\section{Research Method}

The category of this study is reform research oriented. According to Terry Hutchison, "reform oriented research is research which intensively evaluates the adequacy of existing rules and which recommended changes to any rules found wanting" 1 . This study uses Legal Normative method with statue approach.

\section{Discussion}

\section{The Principles of Legislation's Formation}

Legislation Rule according to Article 1 No. 2 of Law No. 12 of 2011 is a written regulations containing binding legal norms in general and formed or defined by state agencies or the competent authority through the procedure laid down in legislation. The rule of no par value shares which attached in Article 31 paragraph (2) Company Law 2007 was a breakthrough for the capital market. The development of Economic in Indonesia should be accompanied by the development of Indonesian law because there will be economic order which will be formed in accordance with the basic principles of the economy of Indonesia. There are two issues which, according to Perry ${ }^{2}$ became the basis of the debate between legal reform and economic development, it was: the relative importance of economic actors across the world on the legal system; and the core component of an effective legal system, as defined by the economic actors.

Economic development should be accompanied by legal reforms. Law serves as a guide

\footnotetext{
Terry Hutchinson, 2002, Researching and Writing in Law, Lawbook, page 9

2 Amanda J. Perry, "The Relationship between Legal Systems and Economic Development: Integrating Economics
}

for the direction of economic actors, as well as public protector. Law must protect and nurture all individuals, in accordance with the provisions of Article 33 of the Constitution 45. If it is associated with the setting of no par value shares, then the benefits of no par value shares is intended for the benefit of market participants, the issuer, the institutions and professions whose activities engaged in capital markets, investors and ultimately benefit the entire nation of Indonesia as supporting the economic development of Indonesia. Article 5 of Law No. 12 Year 2011 on the Establishment of Laws Act (Act No. 12 of 2011), the principle of the establishment of legislation that both include: firts, clarity of purpose; second, institutional or forming appropriate official; third, concordance between types, hierarchies, and substance; fourth, can be implemented; fifth, usefulness and applicated; sixth, the clarity of the formula; and seventh, openness.

According to Article 6, paragraph (1) of Law No. 12 In 2011 the substance of legislation contains the principle: aegis; humanity; nationality; family; kenusantaraan; unity in diversity; justice; quality before the law and government; order and legal certainty; and balance; appropriate, and harmony.

Article 6 Paragraph (2) states that in addition to reflecting the principle referred to in paragraph (1), specific legislation may contain other principles in accordance with the law of legislation concerned. Another principle in accordance with the legal field of legislation is concerned according to the explanation, there are: first, in the Criminal Law, for example, the principle of legality, the principle of no punishment without fault, the principles of coaching inmates, and the presumption of innocence; and second, in the Civil Code, for example, in the law of treaties, among others, the principles of the agreement, freedom of contract and good faith. Another principle referred to in Article 6 paragraph (2) of Act 12 of 2011 in this research

and Cultural Approaches", Journal Of Law and Society, Vol. 29, Number 2. June 2002, Wales: Cardiff University, page 283. 
is the principle of setting no par value shares of which will be explained further.

\section{The Principles of No Par Value Shares Setting}

The principles is a guidelines for achieving the ultimate goal of the legislation, which by Bentham (As its mentioned in Chapter II), is the maximum happiness, the author translated by the author is the achievement of an optimal capital gain. The sign is needed because there is no legislation which is perfect so as to provide protection to the public so that no offense or crime, particularly against the sky is the limit so that it takes the moral law, in this case the setting no par value shares. For legal and moral relationship according to Lon. L Fuller "the morality that makes law possible." 3 But Fuller did not argue that the legal system must comply with the demands of a particular morality or measured from a standard which come from outside the system. Moral guidelines are needed in the manufacture of capital market regulations relating to no par value shares due to limit the issuance of no par value shares is infinite the sky is the limit if not controlled would be bad for the stock market itself.

Article 92 Part Six draft revocation RUUPM torso, Plenary Harmonization Results on March 5, 2012, set:

(1) Public Company may issue shares with a nominal value or no par value shares.

(2) Further provisions regarding to listed no par value shares as referred to in paragraph (1) shall be regulated by the Financial Services Authority regulation.

Article 92 Draft is reiterated that:

a. No par value shares only applies to publicly listed company (PT Tbk.), does not apply to Closed PT.

b. No par value shares applies optionally, PT Tbk may elect to issue shares with-

3 Lon L Fuller, 1969, The Morality Of Law, New Haven: Yale University Press, page 33

4 Stefano Lombardo, "The Comparative, Law and Economic Analysis of Company Law", European Company \& Financial Law Review [tt], Hamburg: School of Law University of Hamburg, page 51. out nominal or fixed value of issued shares with a nominal value.

FSA task to set further provisions of no par value shares must be able to support the realization of efficient capital markets and reasonable. To achieve an efficient capital markets and reasonable and must apply the characteristics of corporate law.

There are 5 characteristics in corporate law that there must be in a good jurisdiction, ${ }^{4}$ there are: first, legal personality/legal entities; second, limited liability (understanding the limit liability, if the company is insolvent, the maximum loss is equal to shareholders' capital they invest); third, transferable shares, is the one which have stocks that easily to transferable; fourth, delegated management under a board structure, the board structure that has manejemen delegation; and fifth, investors ownership, is the ownership of the investment. Because one of the functions of corporate law to minimize the cost of doing business, ${ }^{5}$ then in the setting of no par value shares must be no change in the Indonesian capital market strategy.

There are some drawbacks shares with no par value of which must be considered in its settings, namely: First, restrictions on the issuance of no par value shares was sky (the limit is the sky). The Company can not control the issuing of shares. These actions will be detrimental to investors and creditors that will ultimately have an impact on the stock market itself. Second, according to James $\mathrm{C}$. Bonbright one of the dangers of no par value shares is Stock can be sold at a price that is dishonest. ${ }^{6}$ Third, assets of the Company can not be represented by the number of shares which already issued by the Company. Fourth, there is no protection against creditors as shares have no nominal value. One reason for the Company to issue shares without par value in order to avoid liability on the stock price

\footnotetext{
5 Stefano Lombardo, "The Anatomy of Corporate Law. A Comparative and Functional Approach", European Company \& Financial Law Review, Vol. 8 Issue 1, Feb 2011, Hamburg: School of Law University of Hamburg, page 51.

6 James C Bonbright, "The Dangers of Shares Without Par Value", Columbia Law Review. Vol. 24. No. 5 May 1924, New York: School of Law, Colombia University, page 466.
} 
dropped. There is no obligation for the Company to pay a fixed amount per share. Rickfordpun same opinion. ${ }^{7}$ But this claim was rejected, offered methods of settlement, which requires that all the proceeds of the share capital to the Company to measure the Company's ability to claim the shareholders, so that the Company is not free to issue shares except under strict control.

Based on some of the views over the no par value shares setting at least principled as follows, there are: first, the principle can be applied (workable) by the capital market; second, principles are global (compatible for domestic exchange rules and the world exchange rules); third, the principle of legal certainty gave the sense of fairness (legal certainty in justice); and fourth, the principle to provide protection law (law protection) to the capital market participants, including stakeholders of the capital market. The fourth principle is illustrated in Chart 1.

Chart 1: Setting the no par value shares

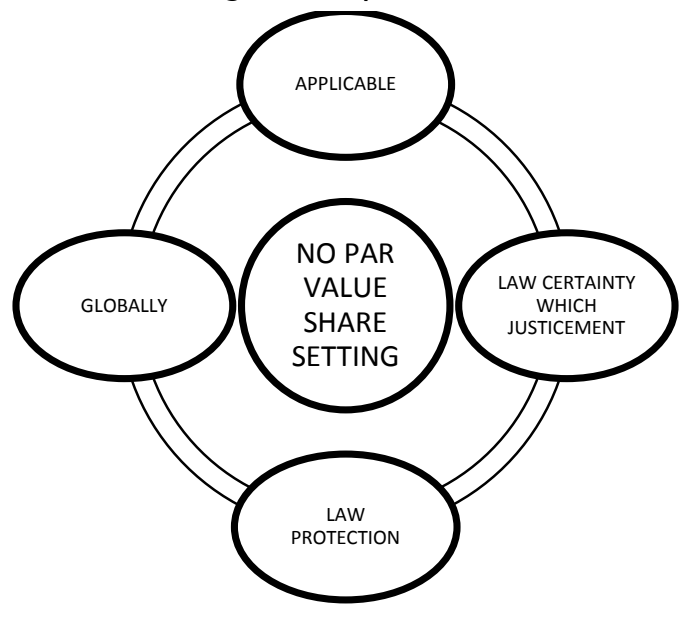

\section{Workable Principle}

According to Mann contained in Comino Vicky writing a rule should apply unless implemented in order to be effective, it is also easy to understand. A regulation can be effective if, based on the potential market and SRO to control his behavior Fuller Company In more details the failure of a rule in the opinion of Rex.

\footnotetext{
Paolo Santella, Ricardo Tarrini, "Capital Maintanance in the EU: Is the Second Company Law Directive Really That Restrictive?", European Business Organization Law Re-
}

Failure of a regulation according to Rex because of a failure to the make rules understandable and the enactment of contradictory rules, because the rules must be applied by the market participants. Regulators must understand the needs of the market will be protect their activities or respond to the needs of society in this respect the capital market.

Responding to the needs of the capital market is the implementation of policies contained in the considerations as well as a general explanation of laws in the economic field. The mention of the objectives of the Act to respond to the needs of society or in order to realize a just and prosperous society, not merely a formality but earnestly respond to the needs of the community will make a failure to the make rules understandable.

Lack of socialization can make a rule not useful, because failure to publicize. BEI within one of the activities is to educate the public about the capital market.

\section{Globalization Principle}

Globalization which caused by the progress of technologi information make borders between countries become nothing (borderless) in the field of communications. Ease of communication between people from different countries becomes easier and faster, even more popular with the term real time. These developments affect business transactions in all fields, one of them in the capital market. Investors can trade on the stock exchanges throughout the world, without having a physical presence. Definition of economic globalization is closely associated with free trade. Trying to create a free trade area of wider trade and eliminating barriers that can lead unsmooth international trade, in this case the trade in the stock market.

Global economy according to Nigel Dower, "the global economy to be sub-set of economic activities which involves transnational transaction, either in the form of trading across bordrs in commodities or finance or in the form of in-

view, No. 9, 2008, Cambridge: Cambridge University, page 444. 
vestment and employment activities by companies whose operations occur in more than one county". ${ }^{8}$ Even André Faria divide globalization in the financial field in two waves, namely, "the first wave of financial globalization (pre World War 1), the second wave of financial globalization (the modern era)." Globalization in financial field, brought some positive changes, namely "financial structures of markets and the world of finance is changing." 10 In globalization era, national law in addition to containing the local characteristics such as the ideology of the nation, the conditions of man, nature and traditions of the nation should also contain the tendencies that are recognized by the civilized world community. ${ }^{11}$

The principle of setting shares without par value of the global nature of global competition faced by Indonesian capital market is global competition in terms of legal certainty and adequate legal tools. This competition occurs because capital markets law have a universal nature. The universal nature is due to the similarity of mechanisms and systems in the capital markets worldwide. ${ }^{12}$ Legal certainty and adequate legal tools are very influential on the increase in the volume and value of trading on the stock exchange.

Based on above explanation, then according to the authors' conclusion that the legislation applied to be appropriate or compatible. The global nature of the arrangement stock without par value, at least among the ASEAN countries, without sacrificing the interests of the Indonesian economy.

8 Nigel Dower, 2002, "Global Economy, Justice, and Sustainability: Ethical Theory and Moral Practice", Netherland. Kluwer Academic Publishers, page 412.

9 André Faria, et al,"The External Financing of Emerging Markets-Evidence from Two Waves of Financial Globalization", Review of Finance, Vol 15 2011, Oxford: European Finance Association, page. 207.

${ }^{10}$ Dilip K. Das,"Globalization in the World of Finance: An Analytical History", Global Economy Journal, Canada: Internaional Trade and Finance Association, Volume 6, Issue 12006 Article 2, page. 1.

11 Yohanes Suhardin, "Harmonisasi dan Sinkronisasi Hukum Nasional dalam Menyikapi Era Globalisasi, Yustisia, No. 75 September-Desember 2008 Edition, Surakarta: Sebelas Maret University, page. 81

12 Rochani Urip Salami, "Hukum Pasar Modal dan Tanggung Jawab Sosial”, Jurnal Dinamika Hukum, Vol .11 No 3 Sep-

\section{Legal Certainty in Justice Principle}

Regulations which changes without the accompaniment of a clear legal political economy will undermine the market. Legal certainty is essential for market participants to trade shares. Legal uncertainty will impact on investors to invest. ${ }^{13}$ The intent of the rule of law, according to Max Weber is "legal Certainty was essential to capitalism". ${ }^{14}$ There are two things about legal certainty, which is the rationale for the application of shares without par value of which is based on economic principles. That is no coercion through legal controls to guarantee the value of the property, and money to secure the enforcement of civil law ${ }^{15}$ and the interpretation and enforcement of contracts relating to companys' bankrupt through court decisions. ${ }^{16}$

Legal certainty must depict justice. In my opinion there is no justice if there is no legal certainty, while there is legal certainty, because of expediency. Justice is something essential to the rule, because of the absence of justice, the purpose of the law is for the benefit of interested parties is reached. Advantages of setting no par value shares of profits earned that capital market participants with trading no par value shares in exchange (BEI).

The sense of justice is very normative and wide, indeed. Philosophy of Law provides a perspective that's justice embodied in law. ${ }^{17}$ Justice becomes ideal element in law, namely as an ideal or an idea that is contained in all the laws. ${ }^{18}$ Therefore the law is supposed to contain the values of justice, but the law itself is not

tember 2011, Purwokerto: Law Faculty of Jenderal Soedirman University, page. 441.

13 Imaniar Yuniasafitri, "Implementasi Peraturan Pemerintah terkait dengan Kepemilikan Saham dari Modal Asing", Unnes Law Journal, Vol. 1 (1) 2012, Semarang: Semarang State University, page 35

${ }^{14}$ Arthur L Stinchcombe, "Certainty of the Law: Reasons, Situation Type, Anology, and Equiibrium", The Journal of Political Philisophy, Vol. 7 No. 3, 1999, page 209.

15 Ibid.

16 Ibid.

17 Inge Dwivismiar, "Keadilan dalam Perspektif IImu Hukum”, Jurnal Dinamika Hukum, Vol. 11 No. 3, September 2011, Purwokerto: Law Faculty of Jenderal Soedirman University, page 530.

18 Bahder Johan Nasution, "Kajian Filosofis tentang Konsep Keadilan dari Pemikiran Klasik sampai Pemikiran Modern”, 
identical to justice because there are legal norms that do not contain the value of justice. ${ }^{19}$

Some experts gave the sense of justice with variance. Kelsen translate justice as a right and ethics. ${ }^{20}$ According to John Rawls, there are two principles of justice (two principles of justice), there are: first, each person is to have an equal right to the most extensive basic liberty compatible with a similar liberty for others; second, social and economic inequalities are to be arranged so that they are both (a) reasonably expected to be everyone's advantage, and (b) attached to positions and offices open to all. ${ }^{21}$ Because justice is equality, then according to Rawls justice will be achieved if both above aspects comprehensively applied.

According to the authors legal certainty that is equitable, is the assurance given by law to provide protection to market participants, as it's institutions, individuals directly involved in the stock market, based on justice, but also to stakeholders, because the purpose of the law (in the broad sense while in the narrow sense legislation) is a legal protection. Rule said to contain legal certainty when making authoritative solution, in accordance with the purpose of the legislation, efficiency, contain aspects of stability and equality ${ }^{22}$

Legal certainty is essential in the capital market but can not be steady, "legal certainty decreases over time" 23 , then the setting shares without par value shall be as umbrellas (blue sky (aw). Setting operational or technical nature submitted to the FSA, and 3 SROs, the BEI, KPEI, $\mathrm{KSEl}$ so it can be adapted to market needs with-

Yustisia, 89 May-August 2014 Edition, Surakarta: Sebelas Maret University, page. 130.

19 See Tata Wijayanta, "Asas Kepatian Hukum, Keadilan dan Kemanfaatan dalam Kaitannya dengan Putusan Kepailitan Pengadilan Niaga”, Jurnal Dinamika Hukum, Vol. 14 No. 2 May 2014, Purwokerto: Law Faculty of Jenderal Soedirman University, page 221.

20 Helga Varden, "Kant and Lying to the Murderer at the Door . . . One More Time: Kant's Legal Philosophy and Lies to Murderers and Nazis", Journal of Social Philosophy, Vol. 41 No. 4, Winter 2010, page 406.

21 John Rawls, 1971, A Theory Of Justice, United Sated Of America. President and Fellow of Harvard College, page 60.

22 Fence M. Wantu, Mewujudkan Kepastian Hukum, Keadilan dan Kemanfaatan dalam Putusan Hakim di Peradilan Perdata, Jurnal Dinamika Hukum, Vol. 12 No. 3 September out ignoring the other principles, that can be applied, are global and provide protection.

\section{Law Protection Principle}

Legal protection is a matter of principle for capital market players to invest in the stock market due to risk. To eliminate the risk necessary to have principles that can protect shareholder or investor in no par value shares setting. Legal protection is primarily the legal protection to investors from the evil corporate or individual. Corporate crime can appear in the form of deed or action officers and/staff who conduct activities for the benefit of the corporation ${ }^{24}$ as well as for his own benefit, known as insider trading. Insider trading is done by top executives, according to research Beneish and Vargus (2002) relates to financial information ${ }^{25}$.

In order to give legal protection to investors and other capital market participants, it is necessary openness principle (the principle of disclourse) and the principle of equality and fairness (the principle of fairness). The main reason of the openness principles, is for the benefit of investors, shareholders have legal protection, one of the ways that the openness of the Issuer. Disclosure of information that is relevant, timely and continuous is the right of the public, especially shareholders and investors ${ }^{26}$.

Law enforcement to provide protection to investors as well as sanctions against insider trading in the markets that are growing are sometimes weak, so that ontime reporting, is an important tool to reduce insider trading, leaks and rumors in the markets. ${ }^{27}$ Relevant information

2012, Purwokwerto: Jenderal Soedirman University, page. 483

23 Anthony D’Amato, “Legal Uncertainty”, California Law Review, Vol. 71 No 1 January 1983, Barkeley: UC Barkeley School of Law, page. 1.

24 Tjandra S Pradjonggo, “Alternatif Sanksi Pidana dalam Kejahatan Korporasi”, Yustisia, 80 May-August 2010, Surakarta: Sebelas Maret University, page. 75

25 Rowland B.F Pasaribu, "Informasi Anomali Akrual dalam Pembentukan Portofolio Saham", Accountancy and Business Journal, Vol 10 No 1 February 2010, Surakarta: Sebelas Maret University, page. 26.

26 Danri T Siboro, "Hubungan Good Corporate Governance dan Pengungkapan Laporan Keuangan”, Economics' Foccus, Vol. 2 No. 2 December 2007,Semarang: STIE Pelita Nusantara, Page 18

27 Adiya Septiani, "Faktor-faktor yang Mempengaruhi Ketepatwaktuan Pelaporan Keuangan Pada Pasar Modal yang 
will assist investors in making rational decisions because it can be used to assess the performance of the company. ${ }^{28}$ The principle of openness is very important in the capital market to give a sense of security to investors in stocks. ${ }^{29}$

Basic openness philosophy or disclourse, is to protect investors' capital markets, so that the principle of openness in many countries is mandatory for issuers, including Australia, to be operationalized with efisen market and reasonable. ${ }^{30}$ The principle of openness or transparency principle is the opportunity to gain access to material information at the same time to all investors who will create capital markets fair, orderly and efficient. Disclosure of information is necessary because the information is very important for making investment decisions in the transaction in the capital market. Application of the principle of openness (disclousure) is an international standard that should be applied in each of the capital market in any country, "Our requirements are benchmarked against international standards and are in line with best practices from developed jurisdictions." 31

Principle of Equality and Fairness suggests that the capital market, every market participants have the same right to receive the same information at the same time. If there are those who have information, but with hold information, or give false information in order to profit from it is a crime in the capital market. Crime in the capital markets is called insider trading if the information owned by parties that belong to the category of people inside.

\section{Closing}

\section{Conclusion}

Based on the Law of the Republic of Indonesia No. 12 of 2011 on the Formation of legislation there are several principles that must

Sedang Berkembang: Perspektif Teori Pengungkapan, Thesis, Accountancy Science Postgraduate Program Diponegoro University, Semarang, December 2015.

${ }^{28}$ Sri D Yusuf, Atim D and Harry S, "Analisis Reaksi Investor terhadap Pengumuman Right Issue di Bursa Efek Jakarta", Wacana, Vol 12 No 4 September 2009, Malang: Postgraduate Program Brawijaya University, Page 793.

29 Abdul Halim Barkatullah, "Penerapan Prinsip Keterbukaan dalam Pasar Modal Syariah”, Jurnal Cakrawala, 2013, Ban- be met in the formation of legislation. These principles include clarity of objectives, institutional or forming proper officials, the correspondence between types, hierarchies, and substance, can be implemented, usefulness, formulation clarity and openness.

Setting shares without par value in the trading of shares in Indonesia at least principled or berasas on (a) the principle can be applied (workable) by the capital market; (b) the principle of a global nature (compatible for domestic exchange rules and the world exchange rules); (c) the principle of legal certainty gave the sense of fairness (legal certainty in justice); (d) the principle to provide protection law (law protection) to the capital market participants, including stakeholders of the capital market.

\section{Suggestion}

Based on the results of this study suggested that regulators in drafting regulations on stock without par value meets the four (4) principles, as already mentioned in the above conclusion. These principles are very important to encourage the development of capital markets in the era of globalization. In addition to these principles will provide legal protection to the capital market so that they do not doubt in carrying out its activities.

\section{Bibliography}

Austin, R P and I M Ramsay. 2010. Ford's Principles of Corporations Law. Australia. Lexis Nexis;

Bonbright, James C. "The Dangers of Shares Without Par Value". Columbia Law Review. Vol. 24. No. 5 (May, 1924). New York: School of Law Colombia University;

Barkatullah, Abdul Halim. "Penerapan Prinsip Keterbukaan dalam Pasar Modal Syariah”. Jurnal Cakrawala. 2013. Banjarmasin:

jarmasin: Law Faculty Lambung Mangkurat University, page 17, available at website http://www. eprints.unlam. ac.id/.../Jurnal\%20Cakrawala\%20PMIH_Prinsip\%20Keterb .., accesssed on $27^{\text {th }}$ May 2015.

30 R P Austin and I M Ramsay, 2010, "Ford's Principles of Corporations Law”, Australia. Lexis Nexis, page. 570.

31 Ibid. 
Law Faculty of Lambung Mangkurat University, page. 17, available at website http: / /www.eprints.unlam.ac.id/.../Jur nal\%20Cakrawala\%20PMIH_Prinsip\%20Ket erb.., accessed on May, 27 2015;

Comino, Vicky. "Effective Regulation by The Australian Securities and Investment Commission: The Civil Penalty Problem". Melbourne University Law Review, Vol 33 No 3 2009. Melbourne: Melbourne Law School;

D’Amato, Anthony. "Legal Uncertainty". California Law Review, Vol. 71 No. 1 January 1983. Barkeley: UC Barkeley School of Law;

Das, Dilip K. "Globalization in the World of Finance: An Analytical History". Global Economy Journal, Vol. 6, Issue 1 2006. Canada: Internaional Trade and Finance Association;

Dwivismiar, Inge. "Keadilan dalam Perspektif IImu Hukum”. Jurnal Dinamika Hukum. Vol. 11 No 3 September 2011. Purwokerto: Law Faculty of Jenderal Soedirman University;

Dowe, Nigel. 2002. Global Economy, Justice, and Sustainability, Ethical Theory and Moral Practice. Netherland: Kluwer Academic Publishers;

Faria, André, et al. "The External Financing of Emerging Markets-Evidence from Two Waves of Financial Globalization". Review of Finance, Vol 15 2011. Oxford: Erupean Finance Association;

Fuller, Lon L. 1969. The Morality Of Law. Yale University;

Hutchinson, Terry. 2002. Researching and Writing in Law. Lawbook;

Lombardo, Stefano. "The Comparative, Law and Economic Analysis of Company Law”. European Company \& Financial Law Review [tt]. Hamburg: School of Law University of Hamburg;

Lombardo, Stefano. "The Anatomy of Corporate Law. A Comparative and Functional Approach". European Company \& Financial Law Review, Feb 2011, Vol. 8 Issue 1, Hamburg: School of Law University of Hamburg;

Lombardo, Stefano. "The comparative, law and economic analysis of company law". European Company 7 Financial Law Review [tt].;

Nasution, Bahder Johan. “Kajian Filosofis tentang Konsep Keadilan dari Pemikiran Kla- sik sampai Pemikiran Modern". Yustisia, 89 Edition May-August 2014. Surakarta: Sebelas Maret University;

Pasaribu, Rowland B.F. “Informasi Anomali Aktual dalam Pembentukan Portofolio Saham”. Jurnal Akuntansi dan Bisnis. Vol 10 No. 1 February 2010. Surakarta: Sebelas Maret University;

Perry, Amanda J. "The Relationship between Legal Systems and Economic Development: Integrating Economics and Cultural Approaches". Journal Of Law and Society, Vol 29, No 2. June 2002. Wales: Cardiff University;

Pradjonggo, Tjandra S. "Alternatif Sanksi Pidana dalam Kejahatan Korporasi”. Yustisia, 80 Edisi May-August 2010. Surakarta: Sebelas Maret University;

Rawls, John. 1971. A Theory Of Justice. President and Fellow of Harvard College. United Sated Of America;

Salami, Rochani Urip. "Hukum Pasar Modal dan Tanggung Jawab Sosial”. Jurnal Dinamika Hukum. Vol .11 No 3 September 2011. Purwokerto: Law Faculty of Jenderal Soedirman University;

Santella, Paolo. and Ricardo Tarrini. "Capital Maintanance in the EU: Is the Second Company Law Directive Really That Restrictive?". European Business Organization Law Review, No. 9 2008. Cambridge: University;

Septiani, Adiya. 2015. “Faktor-faktor yang Mempengaruhi Ketepatwaktuan Pelaporan Keuangan Pada Pasar Modal yang Sedang Berkembang: Perspektif Teori Pengungkapan”. Thesis. Semarang: Accountancy Science Post-graduate Program of Diponegoro University;

Siboro, Danri T. “Hubungan Good Corporate Governance dan Pengungkapan Laporan Keuangan". Economics Foccus. Vol 2 No. 2 December 2007. Semarang: STIE Pelita Nusantara;

Stinchcombe, Arthur L., "Certainty of the Law: Reasons, Situation Type, Anology, and Equilibrium". The Journal of Political Philisophy, Vol. 7 Number 3. 1999;

Suhardin, Yohanes, "'Harmonisasi dan Sinkronisasi Hukum Nasional dalam Menyikapi Era Globalisasi". Yustisia, No. 75 SeptemberDecember 2008. Surakarta: Sebelas Maret University; 
Varden, Helga. "Kant and Lying to the Murderer at the Door ... . One More Time: Kant's Legal Philosophy and Lies to Murderers and Nazis". Journal of Social Philosophy. Vol. 41 No. 4 Winter 2010;

Wantu, Fence M. "Mewujudkan Kepastian Hukum, Keadilan dan Kemanfaatan dalam Putusan Hakim di Peradilan Perdata". Jurnal Dinamika Hukum, Vol. 12 No. 3 September 2012. Purwokerto: Jenderal Soedirman University;

Wijayanta, Tata. "Asas Kepatian Hukum, Keadilan dan Kemanfaatan dalam Kaitannya dengan Putusan Kepailitan Pengadilan Niaga", Jurnal Dinamika Hukum, Vol. 14 No. 2 May 2014. Purwokerto: Law Faculty of Jenderal Soedirman University;

Yuniasafitri, Imaniar. "Implementasi Peraturan Pemerintah terkait dengan Kepemilikan Saham dari Modal Asing". Unnes Law Journal. Vol. 1 (1) 2012. Semarang: Semarang State University.

Yusuf, Sri D, Atim D dan Harry S. "Analisis Reaksi Investor terhadap Pengumuman Right Issue di Bursa Efek Jakarta". Wacana. Vol 12 No 4 September 2009. Malang: Postgraduate Program of Brawijaya University. 